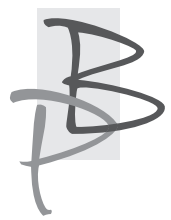

Irena Masojć*

Vytautas Magnus University. Akademia Edukacji, Wilno

https://orcid.org/0000-0001-7492-946X

\title{
Kluczowe pojęcia powieści Witolda Gombrowicza Ferdydurke w przekładzie na język litewski
}

Streszczenie: Język powieści Witolda Gombrowicza Ferdydurke (neologizmy słowotwórcze, semantyczne i frazeologiczne) ma ogromne znaczenie dla zrozumienia sensu filozoficznego dzieła, dlatego jej przekład na inne języki jest dla tłumaczy nie lada wyzwaniem. W 2004 r. na język litewski tę powieść przełożyła znana tłumaczka Irena Aleksaitè. Celem artykułu jest zweryfikowanie trafności przekładu kluczowych pojęć powieści "pupa“, „łydka“ i "gęba“, które stały się symbolami zjawisk społecznych i psychologicznych, oraz zgodności ich litewskich odpowiedników (pupa - užpakalis, užpakaliukas, łudka - blauzda, gęba - snukis, marmūzè) z oryginałem. W artykule analizuje się ekwiwalencję znaczenia semantycznego i barwy stylistycznej odpowiedników litewskich. Analiza pokazuje, że leksemy potoczne, wywołujące określone konotacje pragmatyczne w jednym języku, nie zawsze mają dokładne ekwiwalenty semantyczne, stylistyczne i pragmatyczne w innym języku. Straty językowe w tym przypadku kompensuje kontekst użycia pojęć kluczowych oraz trafne ko-

Irena Masojć - dr, docent w Centrum Języka Polskiego i Kultury Polskiej Akademii Edukacji Uniwersytetu Witolda Wielkiego. Autorka m.in. monografii Regionalne cechy systemu gramatycznego współczesnej polszczyzny kulturalnej na Wileńszczyźnie (2001), we współautorstwie z J. Rieger, K. Rutkowską Słownictwo polszczyzny gwarowej na Litwie (2006). Opublikowała serię artykułów na temat specyfiki form adresatywnych w polszczyźnie wileńskiej oraz polsko-litewskich problemów przekładowych. 
lokacje. Stosowanie dwu odmiennych ekwiwalentów należy oceniać jako chybione tłumaczenie, ponieważ nie utrwalają się one w podświadomości czytelnika jako ważne pojęcia filozoficzne, co przeszkadza dogłębnie pojąć pierwotny zamysł autora.

Słowa-klucze: Gombrowicz, przekład literacki, pojęcia kluczowe, stylistyka.

\section{Key concepts of the novel Ferdydurke by Witold Gombrowicz in Lithuanian translation}

Summary: The language of the novel Ferdydurke by Witold Gombrowicz is of great importance for the understanding of the philosophical meaning of the work, and therefore its translation into other languages is a big challenge. In 2004, Irena Aleksaite translated the novel into Lithuanian. The purpose of this article is to assess the compatibility of Lithuanian equivalents (pol. pupa - lit. užpakalis, užpakaliukas, pol. łydka - blauzda, pol. gęba - lit. snukis, marmūzè) with the concepts of "bottom", "calf" and "mouth", which have become symbols of social and psychological phenomena. The article analyzes the accuracy of the semantic value of Lithuanian equivalents, and the compliance of the stylistic tone. The analysis shows that the vocabulary of a spoken language, which has some pragmatic connotations in one language, does not always have accurate semantic, stylistic and pragmatic equivalents in another language. In these cases, language restrictions are outweighed by the context of a significant use and a significant collocation. The use of two different equivalents should be seen as an inappropriate translation, because in this way they do not constitute important philosophical concepts in the reader's subconscious mind, that makes it difficult to accurately understand the original intention of the author.

Key words: Gombrowicz, literary translation, key concepts, stylistics.

\section{Reikšminės Witoldo Gombrowiciaus romano Ferdydurkẻ sąvo- kos vertime į lietuvių kalbą}

Santrauka: Witoldo Gombrowicziaus romano „Ferdydurkè“ kalba (naujadarai, neosemantizmai, nauji frazeologiniai junginiai) turi didelę reikšmę kūrinio filosofinès prasmès suvokimui, todèl jo vertimas i kitas kalbas tampa dideliu iššūkiu. [ lietuvių kalbą romaną 2004 metais išvertè patyrusi vertèja 
Irena Aleksaitè. Šio straipsnio tikslas - jivertinti reikšminių kūrinio sąvoku "pupa“, „łydka“ ir "gęba“, kurios tapo socialinių ir psichologiniu reiškinių simboliais, lietuvišku ekvivalentų (pupa - užpakalis, užpakaliukas, łydka - blauzda, gęba - snukis, marmūzè) atitikimą originalui. Straipsnyje nagrinèjamas lietuvių kalbos ekvivalentų semantinès reikšmès tikslumas, stilistinio atspalvio atitikimas. Analizè rodo, kad šnekamosios kalbos leksemos, keliančios vienoje kalboje tam tikras pragmatines konotacijas, ne visada kitoje kalboje turi tikslius semantinius, stilistinius ir pragmatinius atitikmenis. Tais atvejais kalbini apribojimą padeda įveikti reikšminiu sąvoku vartojimo kontekstas ir taiklios kolokacijos. Dvieju skirtingu atitikmenu vartojimą reikia vertinti kaip netinkamą vertimą, kadangi tokiu būdu skaitytojo pasąmonèje jie neįsitvirtina kaip svarbios filosofinès sąvokos, o tai trukdo nuodugniai perprasti originalo autoriaus sumanymą.

Raktiniai žodžiai: Gombrowicz, literatūrinis vertimas, raktinès sąvokos, stilistika.

Jeżeli wyjdziemy z ogólnie znanego założenia, że źródłem problemów przekładowych są różnice kulturowe i językowe, to należy stwierdzić, że niewątpliwym wyzwaniem dla tłumaczy jest Ferdydurke Witolda Gombrowicza ${ }^{1}$. Jest to powieść wielowarstwowa, z jednej strony - poprzez liczne odniesienia staropolskie, gwarowe, mocno osadzona w polskim kontekście kulturowym, z drugiej zaś - dzięki stworzonej przez autora siatce pojęć przekazująca uniwersalne treści filozoficzne, które są zakodowane w języku.

Gombrowicz łączy różne gatunki. Ferdydurke w zasadzie składa się z trzech części: w początkowych partiach książki mamy historię o dojrzewaniu, dalej autor kreuje coś w rodzaju powieści nowoczesnej, gdzie nowy, swobodny obyczaj konfrontowany jest ze staroświecczyzną i zacofaniem, w trzeciej części zaś modelem wykorzystanym przez autora jest powieść o polskim dworze,

1 W opublikowanym niedawno studium translatologicznym poświęconym przekładom utworów Gombrowicza w różnych językach największego zainteresowania badaczy doczekała się powieść Ferdydurke - spośród 18 tekstów aż dziewięć poświęca uwagę tej powieści pisarza. Zob. Gombrowicz i tłumacze, red. E. Skibińska, Łask 2004. 
z właściwą jej apoteozą dawnego obyczaju i tradycyjnych wartości. Te części przeplecione zostały dwiema nowelkami, które poprzedza refleksja odautorska o literaturze i losie pisarza. W warstwie językowej utworu odkrywamy szereg stylizacji, aluzji, (krypto)cytatów - to ze Słowackiego, to z Krasińskiego, to z Rabelais'go. Zestawianie różnych stylów literackich było ulubionym chwytem literackim Gombrowicza - w ten sposób, między innymi, uzyskiwał „dystans do Formy"2.

Zdaniem Włodzimierza Boleckiego ${ }^{3}$ mimo skrupulatnych analiz i interpretacji Ferdydurke ciągle niepokoi czytelników swoją zagadkowością, a źródło fantastyki tkwi „w samym języku, w samym akcie opowiadania, który jest «napędzany» nie relacjami o rzeczywistych wydarzeniach, [...] lecz znaczeniami wyrażeń językowych (a więc frazeologią, stereotypami językowymi, logiką składni, cytatami), a przede wszystkim - znaczeniami metafor i pojęć zamienionych w postacie i wydarzenia powieści”" Jerzy Jarzębski uważa, że „Gombrowicz - jak każdy wielki innowator językowy - jest skrajnie trudny do thumaczenia"'5. Fenomen językowy powieści polega na tym, że Gombrowicz tworzy własny język, pewne zwroty leksykalizują się, stają się hasłami, wręcz prowokują rozwój akcji, obrastają we frazeologię. Nad niektórymi przekładami, na przykład hiszpańskim, pracują całe grupy osób, dyskutując każdy trudniejszy zwrot, idiom czy neologizm ${ }^{6}$. Powstają powtórne przekłady na języki obce, aby możliwie najtrafniej przekazać czytelnikom sens powieści Gombrowicza.

2 J. Jarzębski, Między chaosem a forma - Witold Gombrowicz, [w:] Prozaicy dwudziestolecia międzywojennego. Sylwetki, red. B. Faron, Warszawa 1972, s. 257.

3 W. Bolecki, Przewodnik po labiryncie, [w:] Witold Gombrowicz, Ferdydurke, Kraków 2007, s. 266.

4 Tamże, s. 278.

5 J. Jarzębski, dz. cyt., s. 278.

6 Przekładu na język hiszpański dokonywał sam Witold Gombrowicz, korzystając z pomocy argentyńskich przyjaciół. Po latach wspominał: „Zabrałem się więc do pracy, która tak wyglądała: naprzód ja tłumaczyłem, jak mogłem, z polskiego, a potem zanosiłem maszynopis do kawiarni Rex, gdzie moi przyjaciele argentyńscy przerabiali wraz ze mną zdanie po zdaniu, szukając słów właściwych, walcząc ze składnią, z nowotworami, $\mathrm{z}$ duchem języka [...]. Wkrótce to tłumaczenie zaczęło przyciągać ludzi, na niektórych sesjach w Rexie bywało kilkanaście osób [...]”. Zob. W. Gombrowicz, Dziennik 19531956, Kraków 1997, s. 219-220. 
W Ferdydurke w sposób jaskrawy ujawniają się dwie funkcje języka: naznaczone określonym stylem wypowiedzi bohaterów tworzą surrealistyczny świat przedstawiony, narrator natomiast próbuje ten świat wyjaśnić i zinterpretować, obudowując go systemami pojęciowymi ${ }^{7}$ Poszczególne słowa języka potocznego występują w funkcji zwięzłych wykładników rozbudowanych koncepcji filozoficznych Gombrowicza. Dzięki temu powieść z doraźnej satyry przekształca się w utwór o charakterze filozoficznym - w filozoficzną parabolę losu jednostki w społeczeństwie. Gombrowicz posługuje się językiem osobliwym i oryginalnym, ,skondensowanym i zinstrumentowanym, którego powtarzalne frazy i tematy tworzą prawdziwie muzyczną całość"8. Na użytek swego utworu i treści, które chce przekazać, używa kilku pojęć-symboli, które można uznać za słowa kluczowe w tym utworze. O istotnych kwestiach społecznych i psychologicznych mówi, posługując się pojęciami „pupa”, „łydka”, „gęba”. Są to nie tylko nazwy części ciała, które nigdy nie były uwznioślone, jak serce czy głowa, lecz na domiar tego są nacechowanymi stylistycznie synonimami ich nazw neutralnych. Stanowią one elementy groteski i pozwalają tworzyć absurdalną, wynaturzoną rzeczywistość. Krzysztof Hejwowski ${ }^{9}$ stwierdza, że struktury nacechowane językowo, które wymagają głębokiej wiedzy na temat języka wyjściowego, z całą ostrością ujawniają się w przekładzie.

W niniejszym artykule chciałabym omówić kwestie związane z przekładem nazw tych pojęć w litewskiej adaptacji powieści Witolda Gombrowicza. Celem artykułu jest zweryfikowanie adekwatności litewskich odpowiedników leksykalnych w kontekście metaforycznego odczytania tego utworu.

Ferdydurke jest drugim utworem Witolda Gombrowicza (po Dziennikach), który został w 2004 roku oddany czytelnikom litewskim. Tłumaczenia dokonała Irena Aleksaitè, zawodowa tłumaczka, która ukończyła Moskiewski Instytut Literatury im. Gorkiego, dlatego ma w swoim dorobku nie tylko thumaczenia na język litewski, ale też rosyjski. Gombrowicz nie jest jedynym polskim pisarzem, którego na warsztat wzięła Aleksaite, wśród jej przekładów są utwory Józefa Ignacego Kraszewskiego, Marii Rodziewiczówny, Doroty

7 J. Jarzębski, dz. cyt., s. 262.

8 Tamże, s. 265.

9 K. Hejwowski, Kognitywno-komunikacyjna teoria przekładu, Warszawa 2012, s. 105 . 
Terakowskiej, Tadeusza Konwickiego i innych autorów. Na przekład Ferdydurke tłumaczce w 2004 roku przyznane było specjalne państwowe stypendium twórcy sztuki ${ }^{10}$.

W kolejnych częściach artykułu zostaną omówione rozwiązania translatoryczne związane z przekładem kluczowych pojęć-symboli „pupa”, „łydka” i ,gęba”, które w kulturze polskiej z czasem wyszły poza ramy powieści.

\section{Pupa}

Z ciągu synonimów oznaczających część tułowia znajdującą się z tyłu między plecami a udami - siedzenie (pot.), zadek (pot.), pupa (pot.), kuper (pot. żart.), tyłek (pot.), dupa (wulg.), sraka (wulg.), rzyć (wulg. środ.), pośladki11 - autor powieści wybrał leksem pupa, który na tle pozostałych potocyzmów cechuje dodatkowo eufemistyczny charakter. Anna Dąbrowska ${ }^{12}$ uważa, że ten wyraz jest eufemizmem wulgaryzmu dupa, w którym zabieg eufemizacji polega na substytucji pierwszej głoski. Co prawda, można spotkać inne interpretacje jego etymologii: SJPDor ${ }^{13}$ dopuszcza możliwość zapożyczenia wyrazu o tym znaczeniu z języka niemieckiego (niem. Popo), Andrzej Bańkowski natomiast dopatruje się w nim galicyzmu (fr. poupe 'tył; rufa okrętu') ${ }^{14}$. SJPDor zarówno ten leksem, jak i jego derywaty hipokorystyczne: pupka, pupeczka, pupina, pupcia opatrują kwalifikatorem dziec., ograniczając zakres użycia tego wyrazu do komunikacji z dziećmi, a typowe kolokacje tego leksemu zjeżdżać na pupie, pupa niemowlaka, gładki jak pupa niemowlaka świadczą, że w sposób naturalny są one również kojarzone z dziećmi. Należy zaznaczyć, że w SJPDor leksemowi pupa przypisuje się jeszcze inne znaczenie homonimiczne: 1. 'lalka, kukła'. 2. przen. 'kobieta ładna, ale próżna', pochodzące z łaciny (łac. pupa 'dziewczynka, lalka'), opatrzone jednak kwalifikatorem daw., którego nowsze słowniki już nie notują.

10 Informacje zostały zaczerpnięte ze strony: https://www.llvs.lt/narys/4 [dostęp: 28 września 2017 r.]

11 Stownik synonimów polskich, red. Z. Kurzowa, Warszawa 2003.

12 A. Dąbrowska, Eufemizmy współczesnego języka polskiego, Łask 2006, s. 202, 280.

13 Stownik języka polskiego, red. W. Doroszewski, t. I-XI, Warszawa 1958-1969. W analizie celowo wykorzystano słownik najbardziej wiarygodny dla polszczyzny z pierwszej połowy $\mathrm{XX}$ wieku, kiedy to powstała omawiana powieść Gombrowicza, leksykon języka polskiego.

14 A. Bańkowski, Etymologiczny stownik języka polskiego, t. 2, Warszawa 2000, s. 965. 
W utworze Gombrowicza zostały wykorzystane konotacje pragmatyczne, odnoszące leksem pupa do sfery familijnej, w której w taki sposób określa się część ciała małych dzieci. Wybór tego synonimu ma istotne znaczenie dla wymowy utworu, pojęcie „pupa” bowiem jest symbolem infantylizacji, jakiej dorośli dopuszczają się wobec dzieci. Taką motywację semantyczną wyraz pupa narzuca też neologizmowi słowotwórczemu upupić czy sfrazeologizowanym połączeniom wyrazowym typu przyprawić/zrobić pupę, które oznaczają wpędzanie kogoś w niedojrzałość. Ten aspekt znaczeniowy wzmacniają też charakterystyczne kolokacje z epitetami: dziecinna, dziecięca, infantylna, niewinna i inne. Niedojrzałość w powieści rozumiana jest znacznie szerzej, autor Ferdydurke tworzy parabolę relacji międzyludzkich, w których infantylizowanie jest narzędziem manipulacji. Ten, kto ma pupę, jest zmuszony do słuchania i akceptowania poglądów osób „dojrzałych”. Można zatem powiedzieć, że „pupa” jest również znakiem zależności, pewnej „niższości” w kontaktach międzyludzkich. Zdaniem samego pisarza okryta milczeniem niedojrzałość jest nieodłączną cechą natury ludzkiej, skrzętnie skrywaną poprzez tworzenie sztuki, filozofii, moralności, a jego powieść będąca „obrazem walki o własną dojrzałość kogoś zakochanego w swej niedojrzałości”'15, ukazuje dramat człowieka uwikłanego w tę sprzeczność.

Leksem pupa przewija się w całej powieści, w pierwszej części utworu jednak szczegółowo jest opisany mechanizm upupiania, gdy profesor Pimko zmniejsza bohatera Józia i prowadzi do szkoły, w której edukacja polega na infantylizowaniu dorosłych. W tabeli 1. zostały zestawione wybrane przykłady ilustrujące przekład tego pojęcia w litewskiej adaptacji powieści.

15 W. Gombrowicz, Dziennik 1957-1961, t. 2, Kraków 1997, s. 10. 


\section{W. Gombrowicz Ferdydurke $\quad$ W. Gombrowicz Ferdydurk $\dot{e}^{17}$}

\begin{tabular}{|c|c|c|}
\hline 1. & $\begin{array}{l}\text { Chciałem krzyknąć, że nie jestem } \\
\text { uczeń, że zaszła pomyłka, porwałem } \\
\text { się do ucieczki, ale coś mnie z tyłu } \\
\text { chwyciło jak kleszcze i przygwoź- } \\
\text { dziło na miejscu - dziecięca, infan- } \\
\text { tylna pupa mnie chwyciła. Z pupą } \\
\text { nie mogłem się ruszyć... (s. } 20) \text {. }\end{array}$ & $\begin{array}{l}\text { Norèjau sušukti, kad nesu mokinys, } \\
\text { kad ìvyko klaida, pašokau norèdamas } \\
\text { pabègti, bet kažkas iš užpakalio } \\
\text { sugrèbè mane lyg rèplèmis ir prikale } \\
\text { prie kėdès - mane sučiupo vaikiškas, } \\
\text { infantilus užpakalis. Su užpakaliu } \\
\text { negalejjau bėgti... (s. 23). }\end{array}$ \\
\hline 2 & $\begin{array}{l}\text { I siedziałem w nierealnym nonsensie } \\
\text { jak we śnie, zakneblowany, } \\
\text { zbelfrzony i zabelfrowany, } \\
\text { siedziałem na dziecinnej pupci - on } \\
\text { zaś siedział jak na Akropolu i } \\
\text { zapisywał coś w notesie (s. } 21 \text { ). }\end{array}$ & $\begin{array}{l}\text { Ir sėdèjau toje toje nerealioje } \\
\text { nasąmoneje kaip sapne, užkimšta } \\
\text { burna, sumokytojintas ir sumokytas, } \\
\text { sėdejjau ant vaikiško užpakaliuko - } \\
\text { o jis sèdèjo kaip ant Akropolio ir } \\
\text { kažką rašè ị užrašų knygelè (s. 23). }\end{array}$ \\
\hline 3. & $\begin{array}{l}\text { Idiotyczna, infantylna pupa } \\
\text { paraliżowała, odbierając wszelką } \\
\text { możliwość oporu; pędząc truchtem } \\
\text { obok kolosalnego, który sadził } \\
\text { wielkimi krokami, ani rusz nie } \\
\text { mogłem z pupą (s. 22). }\end{array}$ & $\begin{array}{l}\text { Idiotiškas, infantilus užpakalis } \\
\text { paralyžiavo, atimdamas bet kokią } \\
\text { pasipriešinimo galimybę; } \\
\text { skubėdamas ristele šalia milžyno, } \\
\text { kuris žengė didžiuliais žingsniais, su } \\
\text { užpakaliu nė krust negalejjau (s. 24). }\end{array}$ \\
\hline 4. & $\begin{array}{l}\text { Nie ma nic lepszego od matki za } \\
\text { płotem na chłopca w wieku } \\
\text { szkolnym. Nikt nie wydobędzie z } \\
\text { nich bardziej świeżej } \\
\text { i dziecięcej pupy niż matka dobrze } \\
\text { ulokowana za płotem (s. 24). }\end{array}$ & $\begin{array}{l}\text { Nėra nieko geriau nei motina už } \\
\text { tvoros kiekvienam mokyklinio } \\
\text { amžiaus berniukui. Niekas neišgaus } \\
\text { jų sveikesnio ir vaikiškesnio } \\
\text { užpakalio nei motina, patogiai } \\
\text { įsitaisiusi už tvoros (s. 26). }\end{array}$ \\
\hline 5. & $\begin{array}{l}\text {... młodzież męska niewinna jest! } \\
{[\ldots] \text { Dowodem tego - wygląd }} \\
\text { uczniów oraz ich niewinne rozmowy } \\
\text { tudzież ich niewinne i przemile } \\
\text { pupy (s. } 26) .\end{array}$ & $\begin{array}{l}\text {... vyriškos lyties jaunimas yra } \\
\text { nekaltas! [...] Šị teigini pagrindžia ir } \\
\text { irodo mokinių išvaizda bei nekalti } \\
\text { pokalbiai, taip pat jų nekalti ir } \\
\text { puikučiai užpakaliukai (s. } 28 \text { ). }\end{array}$ \\
\hline 6. & $\begin{array}{l}\text { Natychmiast powiedz je [słowo } \\
\text { „dupa”]! To jedyna nasza obrona } \\
\text { przed pupą! Nie widzisz, że } \\
\text { wizytator jest za dębem i pupę nam } \\
\text { robi? (s. 27). }\end{array}$ & $\begin{array}{l}\text { Tučtuojau ji pasakyk! Tai vienintėlis } \\
\text { mūsų apsigynimas nuo užpakalio! } \\
\text { Argi nematai, kad inspektorius } \\
\text { užlindo už ąžuolo ir daro mums } \\
\text { užpakalį? (s. 30). }\end{array}$ \\
\hline
\end{tabular}

16 Do tej analizy wykorzystano polskie wydanie: W. Gombrowicz, Ferdydurke, Kraków 2007.

17 W. Gombrowicz, Ferdydurke, vert. Irena Aleksaite, Vilnius 2004 


\begin{tabular}{|c|c|c|}
\hline 7. & $\begin{array}{l}\text { A matki i ciotki za płotem wpadły } \\
\text { w zachwyt i biorąc się w ramiona } \\
\text { powtarzały: - Cóż za wytrawny } \\
\text { pedagog! Pupcię, pupcię, pupcię } \\
\text { mają maleństwa nasze! (s. 29). }\end{array}$ & $\begin{array}{l}\text { O motinas ir tetas už tvoros apėmè } \\
\text { susižavèjimas, ir jos, susikibusios už } \\
\text { ranku, kartojo: - Koks patyręs } \\
\text { pedagogas! Užpakalị, užpakali, } \\
\text { užpakali turi mūsų mažyliai! (s. 32). }\end{array}$ \\
\hline 8. & $\begin{array}{l}\text { Pupa, pupa, pupa! Dziękuję za } \\
\text { pamięć drogi profesorze! Bóg zapłać, } \\
\text { panie kolego, za nowego ucznia! [...] } \\
\text { Pupa, pupa, pupa. Czy uwierzy pan, } \\
\text { że dorośli, sztucznie przez nas } \\
\text { zdziecinnieni i zdrobnieni, stanowią } \\
\text { jeszcze lepszy element niż dzieci } \\
\text { w stanie naturalnym? Pupa, pupa, } \\
\text { bez uczniów nie byłoby szkoły, } \\
\text { a bez szkoły życia by nie było! } \\
\text { (s. } 38 \text { ). }\end{array}$ & $\begin{array}{l}\text { Užpakalis, užpakalis, užpakalis! } \\
\text { Dėkoju, kad manęs neužmiršti, } \\
\text { brangus profesoriau! Dievas tau } \\
\text { atlygins užnaują mokinį! [...] } \\
\text { Užpakalis, užpakalis, užpakalis. } \\
\text { Ar galite patikèti, kad suaugusieji, } \\
\text { kuriuos dirbtinai suvaikinome ir } \\
\text { sumažybinome, yra dar geresnis } \\
\text { elementas nei natūralūs vaikai? } \\
\text { Užpakalis, užpakalis, be mokinių } \\
\text { nebūtų mokyklos, o be mokyklos } \\
\text { gyvenimo! (s. 41). }\end{array}$ \\
\hline 9. & $\begin{array}{l}{[\ldots] \text { Pimko nie poszukiwałby mnie }} \\
\text { przez policję, tak daleko macki } \\
\text { pedagogii pupiej chyba nie sięgały } \\
\text { (s. 47). }\end{array}$ & $\begin{array}{l}\text { [...] Pimka tikrai neieškotų manęs su } \\
\text { policija, taip toli užpakaliukinès } \\
\text { pedagogijos čiuptuvai tikrai nesiekè } \\
\text { (s. 52). }\end{array}$ \\
\hline 10 & $\begin{array}{l}\text { Widzieliście, jak złośliwie } \\
\text { dydaktyczny Pimko mnie upupil } \\
{[\ldots] \text { (s. 67). }}\end{array}$ & $\begin{array}{l}\text { Matète, kaip pyktybiškai } \\
\text { didaktiškasis Pimka mene suvaikino } \\
{[\ldots] \text { (s. 74). }}\end{array}$ \\
\hline 11. & $\begin{array}{l}\text { Panowie, [...] a jednak moglibyście } \\
\text { w pewnej mierze uratować godność, } \\
\text { oddalając się od Sztuki, która wam } \\
\text { pupę tak kłopotliwą przyprawia } \\
\text { (s. 76). }\end{array}$ & $\begin{array}{l}\text { Ponai }[\ldots] \text {, bet vis dèlto galètumėte iš } \\
\text { dalies išgelbèti savo garbę } \\
\text { pasitraukdami nuo Meno, kuris jums } \\
\text { pritaiso nepatogų užpakalị (s. 84). }\end{array}$ \\
\hline 12. & $\begin{array}{l}\text { Już tam Młodziakowie potrafią go } \\
\text { zdrobnić! Już tam pupę mu zrobią } \\
\text { doskonałą! (s 101). }\end{array}$ & $\begin{array}{l}\text { Jau Jaunatviai tai tikrai isstengs ji } \\
\text { sumažybinti! Jau ten tai tikrai pri- } \\
\text { taisys jam puikų užpakalị! (s. 111). }\end{array}$ \\
\hline 13. & $\begin{array}{l}\text { Czy było to, że Pimko, belfer } \\
\text { klasyczny, mnie upupil, żem był } \\
\text { uczniem w szkole, nowoczesnym } \\
\text { z nowoczesną (s. 181). }\end{array}$ & $\begin{array}{l}\text { Ar buvo taip, kad Pimka, klasikinis } \\
\text { pedagogas, pritaisė man užpakali, } \\
\text { kad buvau mokinys mokykloje, } \\
\text { naujoviškas su naujoviškaja (s. 198). }\end{array}$ \\
\hline 14. & $\begin{array}{l}\text { Księżyc wypływał zza chmur, lecz } \\
\text { nie był to księżyc, tylko pupa. } \\
\text { Pupa niezmiernych rozmiarów nad } \\
\text { wierzchołkami drzew. Dziecięca } \\
\text { pupa nad światem. I pupa. I nic, } \\
\text { tylko pupa (s. 256). }\end{array}$ & $\begin{array}{l}\text { Iš už debesų išlindo mėnulis, bet tai } \\
\text { nebuvo męnulis, tai buvo užpakalis. } \\
\text { Neišmatuojamo dydžio užpakalis } \\
\text { virš medžių viršūnių. Vaikiškas } \\
\text { užpakalis virš pasaulio. Ir užpa- } \\
\text { kalis. Ir nieko, tik užpakalis (s. 280). }\end{array}$ \\
\hline
\end{tabular}

Tabela 1. Przekład pojęcia „pupa“ w litewskiej adaptacji powieści W. Gombrowicza Ferdydurke. 
W litewskim przekładzie na oznaczenie pojęcia „pupa“ został wybrany leksem užpakalis - wyraz o znacznie szerszym zakresie semantyczno-stylistycznym. Jest to neutralny stylistycznie wyraz wieloznaczny. Słownik LKŽe ${ }^{18}$ wymienia przy nim liczne znaczenia: 1.'miejsce znajdujące się z tyłu kogoś lub za kimś, przeciwst. przód', na przykład užpulti ka iš užpakalio 'napadać kogoś z tyłu', stoveti užpakaly 'stać z tyłu'; 2. 'tylna część ciała człowieka lub zwierzęcia'; 3. 'część ubrania, zakrywająca siedzenie'; 4. euf. 'odbyt'; 5. 'tylna część ciała, plecy'; 6. 'tylna część przedmiotu lub budynku', na przykład laivo užpakalis 'rufa statku'; 7. 'obrzeże, zaplecze'; 8. 'przeszłość'. Wszystkie znaczenia tego polisemu wyraźnie łączy semem 'tył czegoś/kogoś', a tylna część ciała jest tylko jednym z wielu znaczeń, w którym leksem užpakalis łączy się w ciągu synonimicznym z takimi wyrazami, jak sedyne, pasturgalis, siubine, šikna (wulg.). Żaden z nich nie wywołuje skojarzeń z dziecięcym ciałem i nie odnosi się do komunikacji z dziećmi, dlatego też w znaczeniu przenośnym również nie może sugerować niedojrzałości.

Wydaje się, że najbliższe polskiej semantyce leksemu pupa oraz intencji autora powieści mogłoby być zdrobnienie užpakaliukas 'tyłeczek', które wskazuje na małe rozmiary i ma pieszczotliwe zabarwienie. W całej książce jednak posłużono się nim tylko sporadycznie. Użycie litewskiego zdrobnienia uwarunkowane jest polskim deminutywem pupcia (por. przykład 2) oraz kolokacją z określeniami kojarzącymi się z niedojrzałością: dziecinna (por. przykład 2), niewinne i przemiłe (por. przykład 5). Zrobnienie užpakaliukas jest też podstawą słowotwórczą przymiotnika relacyjnego w połączeniu wyrazowym užpakaliukine pedagogija odpowiadającym $\mathrm{w}$ oryginale pedagogice pupiej (por. przykład 9). W większości przypadków odpowiednikiem pojęcia „pupy” jednak jest w przekładzie litewskim leksem užpakalis, który wcale nie konotuje niedorosłości i infantylizmu. Połączenia frazeologiczne zrobić/przyprawić komuś pupę, tłumaczy się najczęściej dosłownie: daryti užpakali (por. przykład 6), pritaisyti užpakali (por. przykład 11,12). W przekładzie litewskim znika jaskrawy neologizm czasownikowy upupić, ponieważ tłumaczka nie znajduje w litewskim systemie słowotwórczym odpowiedniego modelu na jego dokładne odwzorowanie. W jednym przypadku oddaje go za pomocą

18 Lietuviu kalbos žodynas. Dostępny w Internecie: www.lkz.lt [logowanie: 28.09.2017]. 
zwrotu frazeologicznego pritaisyti užpakali (por. przykład 13), w innym posługuje się funkcjonalną metodą przekładu, tworząc trafny neologizm suvaikinti ‘uczynić dzieckiem’ (por. przykład 10).

Można zatem stwierdzić, że na skutek braku w języku litewskim dokładnego ekwiwalentu leksykalno-stylistycznego w litewskiej adaptacji powieści częściowo gubi się istotny sens filozoficzny pojęcia „,pupa”, którym jest ono obdarzone w oryginale. Wyraz užpakalis pozbawiony jest nacechowania pragmatycznego, które bezpośrednio nawiązuje do infantylności. Treść tego wyrazu rozmywa jeszcze bardziej jego szeroki zakres znaczeniowy, powodujący, że występuje on w tekście w innych znaczeniach, czasami nawet w tym samym kontekście (por. przykład 1).

\section{Łydka}

Wyraz tydka jest definiowany w SJPDor następująco: 'tylna mięsista część nogi pomiędzy kolanem a stopą, splot mięśni w tylnej okolicy goleni’. Jest to nazwa specyficzna, charakterystyczna wyłącznie dla budowy ciała ludzkiego. Pozostałe dwa synonimy goleń (oraz anat. podudzie) mają szerszy zakres znaczeniowy, stosowane są zarówno w opisie anatomii człowieka, jak i zwierząt, poza tym obejmują swoim znaczeniem zarówno tylną, jak i przednią część tego odcinka nogi człowieka, por. SJPDor. 'część dolnej kończyny człowieka lub tylnej zwierzęcia, zawarta między kolanem a stopą'. W opozycji do nich więc leksem łydka wiąże się z fizyczną tężyzną, młodością i dlatego zawiera pewne konotacje erotyczne.

Gombrowicz uczynił w powieści z pojęcia „łydka” symbol nowoczesnej obyczajowości opartej na kulcie pięknego, zdrowego ciała, młodości, a także swobody obyczajów, w tym swobody erotycznej. Pojęcie ,łydka” łączy się przede wszystkim ze światem Młodziaków, którzy deklarując nowoczesny stosunek do życia, zachęcają swoją córkę do swobodnego, naturalnego zachowania, namawiają wręcz do nieślubnego macierzyństwa. To właśnie postawa Zuty wyraża najpełniej to, co pisarz rozumie przez ,łydkę” - jest ona pełną energii, szczególnie atrakcyjną fizycznie, wyzwoloną dziewczyną, choć w toku powieści okazuje się, że to tylko kolejna przyjęta na użytek otoczenia maska.

We współczesnym języku litewskim mamy właściwie tylko jeden odpowiednik dla wszystkich trzech zróżnicowanych semantycznie i/lub stylistycznie polskich leksemów - blauzda. Podane obok niego w LKŽe synonimy 
staibis, stibynas mają charakter regionalny, pochodzą z zachodniego obszaru dialektalnego języka litewskiego. Poza znaczeniem anatomicznym litewski leksem blauzda używany jest w licznych znaczeniach przenośnych, por. LKŽe: 1. 'część nogi poniżej kolan'; 2. 'getry'; 3. 'stojak jakiegoś urządzenia'; 4. 'belka drabiny'; 5. 'część sochy'; 6. 'pas ziemi'.

Tłumacz litewski nie ma więc w tym przypadku wyboru i może posłużyć się wyłącznie leksemem blauzda, mimo że jego znaczenie jest pojemniejsze i mniej skoncentrowane na umięśnionej części goleni. Podane w tabeli 2. przykłady przekonują, że odpowiednie kolokacje (por. przykład 2) lub konteksty, których bohaterką jest młoda dziewczyna (por. przykład 3,4,5), pozwalają nadać mu konotacje niezbędne do właściwego odczytania zamysłu autora oryginału.

\section{W. Gombrowicz Ferdydurke W. Gombrowicz Ferdydurke}

\begin{tabular}{|c|c|c|}
\hline 1. & $\begin{array}{l}\text { Nogi-podniecał się do nowoczes- } \\
\text { ności - nogi, znam was, znam wasze } \\
\text { sporty, obyczaj nowego zamery- } \\
\text { kanizowanego pokolenia, wolicie } \\
\text { nogi niż ręce, dla was nogi waż- } \\
\text { niejsze, lydki! Kultura ducha dla was } \\
\text { niczym, tylko lydki. Sporty! Lydki, } \\
\text { lydki - pochlebiał mi strasznie-- } \\
\text { lydki, lydki, lydki! (s. 107). }\end{array}$ & $\begin{array}{l}\text { Kojos, - kviete jis ị naujoviškumą, - } \\
\text { kojos, žinau jus, žinau jūsų sportus, } \\
\text { tai naujos amerikanizuotos kartos } \\
\text { paprotys, jūs teikiate pirmenybę } \\
\text { kojoms, o ne rankoms, jums svar- } \\
\text { biausios yra kojos, blauzdos! Dva- } \\
\text { sinė kultūra, palyginti su blauzdo- } \\
\text { mis, jums yra tuščia vieta. Sportai! } \\
\text { Blauzdos, blauzdos, - baisiai } \\
\text { pataikavo man, - blauzdos, } \\
\text { blauzdos, blauzdos! (s. 117). }\end{array}$ \\
\hline 2. & $\begin{array}{l}\text { I było w tym jakieś koleżeństwo } \\
\text { lydek z pensjonarką, plus tajne } \\
\text { rozkoszne porozumienie łydczane, } \\
\text { plus patriotyzm nogi, plus zuchwal- } \\
\text { stwo łydki młodej, plus poezja nogi, } \\
\text { plus młodzieńcza duma łydczana } \\
\text { i kult łydki. (s. 107). }\end{array}$ & $\begin{array}{l}\text { Ir dar jutau kažkokị blauzdų } \\
\text { bendrumą su mokine plius slaptą, } \\
\text { palaimingą blauzdų susikalbėjimą } \\
\text { plius kojos patriotizmą plius jaunos } \\
\text { blauzdos akiplěšiškumą plius kojos } \\
\text { poeziją plius jaunatvišką blauzdinį } \\
\text { išdidumą ir blauzdos kultą. (s. 117). }\end{array}$ \\
\hline 3. & $\begin{array}{l}\text { Pochylona z nogą oparta o krzesełko, } \\
\text { czyściła bucik miękką ściereczką } \\
\text { zamszową [...] i wydawało mi się, że } \\
\text { dziewczynie idzie nie o polor bucika, } \\
\text { ile raczej o to, by lydką i nogą } \\
\text { doskonalić typ swój w tajemnicy } \\
\text { i utrzymać się w dobrym stylu } \\
\text { nowoczesnym (s. 118). }\end{array}$ & $\begin{array}{l}\text { Palinkusi, užkèlusi koją ant kèdutès, } \\
\text { ji minkšta zomšaos skiltele velè } \\
\text { bateli [...] ir man pasirodè, kad } \\
\text { merginai ne tiek rūpi batelio } \\
\text { blizgèjimas, kiek noras blauzda ir } \\
\text { koja paslapčiom stiprinti savo tipažą } \\
\text { ir išlaikyti naujovišką stilių (s. 129). }\end{array}$ \\
\hline
\end{tabular}




\begin{tabular}{|c|c|c|}
\hline 4. & $\begin{array}{l}\text { Te listy dopiero unaoczniły mi całą } \\
\text { potęgę nowoczesnej pensjonarki. } \\
\text { Gdzież jej nie było? W czyjej głowie } \\
\text { nie tkwiły jej lydki? (s. 155). }\end{array}$ & $\begin{array}{l}\text { Tik iš tų laiškų supratau, kokia galin- } \\
\text { ga yra naujoviška pensiono mokinè. } \\
\text { Kur tik jos nebuvo! Kieno tik galvoje } \\
\text { neglūdèjo jos blauzdos! (s. 169). }\end{array}$ \\
\hline 5. & $\begin{array}{l}\text { Łkała z lydkami nagimi, wystają- } \\
\text { cymi spod kołdry, z lydkami, które } \\
\text { w miarę płaczu coraz bardziej } \\
\text { wystawały, a ten płacz nieletniej } \\
\text { łączył Pimkę, Kopyrdę, rodziców, } \\
\text { nizał ich na demonizm jak na } \\
\text { sznurek (s. 178). }\end{array}$ & $\begin{array}{l}\text { Kūkčiojo su nuogomis blauzdomis, } \\
\text { kysančiomis iš po anklodès, su } \\
\text { blauzdomis, kurios jai verkiant lindo } \\
\text { iš po antklodès vis labiau, ir tos } \\
\text { nepilnametės ašaros siejo Pimką, } \\
\text { Kopirdą, tèvus, ant demonizmo tarsi } \\
\text { ant siūlo suvèrejuos visus (s. 194). }\end{array}$ \\
\hline
\end{tabular}

Tabela 2. Przekład pojęcia „łydka“ w litewskiej adaptacji powieści W. Gombrowicza Ferdydurke.

\section{Gęba}

Wyraz gęba został wybrany przez pisarza z całego szeregu synonimów stylistycznych określających twarz człowieka: oblicze (pis.), fizjonomia (rzad.), fizys (pot.), gęba (pot.), facjata (pot.), dziób (pot.), japa (pot.), papa (pot.), paszcza (pot.), pysk (pot.), jadaczka (pot.), maska (slang.), morda (wulg.), ryj (wulg.), ryło (wulg.), buzia (pieszcz.), lice/lico (podn.), buźka (pot.), pysio (żart.) ${ }^{19}$. Można zauważyć, że źródłem ekspresji dla większości wyrazów potocznych, por. dziób, paszcza, pysk/pysio, morda, ryj, ryło jest zoomorfizacja - przenośne wykorzystanie nazw pierwotnie odnoszących się do zwierząt.

SJPDor wymienia w haśle gęba następujące znaczenia: 1. pot. rub. a) 'usta, wargi', b) 'jama ustna (jako miejsce, gdzie się znajdują narządy mowy)', c) 'twarz, policzki'; 2. 'pysk u zwierząt'. Jest to bardzo stary wyraz ogólnosłowiański, który początkowo nie miał zabarwienia stylistycznego i obrósł w bogatą frazeologię, na przykład o suchej gębie 'bez jedzenia i picia', od gęby odejmować 'oszczędzać na jedzeniu', zapomnieć języka w gębie 'zaniemówić'. Ustępując jednak miejsca innych wyrazom bliskoznacznym, nabrał nacechowania rubasznego i wtórnie zaczął być stosowany na oznaczenie pyska niektórych zwierząt.

19 Słownik synonimów polskich, red. Z. Kurzowa, Warszawa 2003. 
Wyrazy twarz i gęba mają związek z wizerunkiem człowieka, na przykład stracić twarz 'stracić dobrą opinię', zrobić (przyprawić) komuś gębę 'stworzyć fałszywy wizerunek kogoś’. Gombrowiczowska „gęba” wyraża kolejny dramat egzystencjalny człowieka, którego wewnętrzne rozdarcie polega na tym, że dąży on do autentyczności, ale jest skazany na wkładanie różnych masek w relacjach międzyludzkich: „Wieczysty aktor, ale aktor naturalny, ponieważ sztuczność jest mu wrodzona, ona stanowi cechę jego człowieczeństwa - być człowiekiem to znaczy być aktorem [...]"20. Pojęcie „gęba” wyraża uzależnienie człowieka od Formy, w którą popadamy, przyjmując społeczne konwenanse, obyczaje i styl bycia. Bohaterowie Ferdydurke przyjmują różne maski: szkoła stara się przyprawić uczniom „gębę” niewinności i naturalności, modni pisarze i publicyści narzucają inteligenckiej rodzinie schemat nowoczesnej, wyzwolonej obyczajowości, ziemianie - z kolei - narzucają służbie „gębę" chamów, a służba ziemianom „gębę” panów. Za każdym razem jednak to fałszuje ludzką naturę, staje się źródłem zła i głupoty. Najczęstsze kolokacje, w których to pojęcie występuje w powieści, to połączenia mieć gębę i robićl wlepić komuś gębę.

\section{W. Gombrowicz Ferdydurke W. Gombrowicz Ferdydurke}

\begin{tabular}{|c|c|c|}
\hline 1. & $\begin{array}{l}\text { Miętus odrzekł z mądrością pijaka: - } \\
\text { A to dlatego masz gębę? Sztama, } \\
\text { Józio! No ale ukochana gębę ci } \\
\text { wlepiła (s. 123). }\end{array}$ & $\begin{array}{l}\text { Miento atsakymas buvo persmelktas } \\
\text { girtuoklio išminties: - Tai dèl to tavo } \\
\text { toks snukis? Draugaukime, Juzi! Na, } \\
\text { bet ir marmūzę tau įtaisè tavo } \\
\text { mylimoji (s. 135). }\end{array}$ \\
\hline 2. & $\begin{array}{l}\text { Ba, ba, jeśli nowoczesna wlepila ci } \\
\text { gębę, to się nie wykaraskasz tak } \\
\text { łatwo. (s. 124). }\end{array}$ & $\begin{array}{l}\text { Cha, cha, jeigu naujoviškoji illipdè } \\
\text { tau snukị taip lengvai neišsikapstysi } \\
\text { (s. 136). }\end{array}$ \\
\hline 3. & $\begin{array}{l}\text { Lecz nie chciała mnie! Gębę mi } \\
\text { robila! I z dniem każdym } \\
\text { straszliwszą robiła mi gębę (s. 132). }\end{array}$ & $\begin{array}{l}\text { Bet ji manęs nenorèjo! Marmūzę } \\
\text { man darè! Ir kasdien vis baisesnę } \\
\text { (s. 144). }\end{array}$ \\
\hline 4. & $\begin{array}{l}\text { Cóż - od dwóch tygodni bez przerwy } \\
\text { robili mi gębę i gęba stała się wresz- } \\
\text { cie tak fatalna, że nawet zazdrościć } \\
\text { już nie miałem z czego (s. 136). }\end{array}$ & $\begin{array}{l}\text { Ką gi - dvi savaitès be perstojo darè } \\
\text { man snukị, ir galop jis tapo toks } \\
\text { atgrasus, kad net pavydèti neturejjau } \\
\text { iš ko (s. 149). }\end{array}$ \\
\hline
\end{tabular}

20 W. Gombrowicz, Dziennik 1957-1961, t. 2, Warszawa 1997, s. 9. 


\begin{tabular}{|c|c|c|}
\hline 5. & $\begin{array}{l}\text { O tym myślałem przygotowując za } \\
\text { drzwiami gębę swą do interwencji. } \\
\text { (s. 172). }\end{array}$ & $\begin{array}{l}\text { Galvijau apie tai už durų, ruošdamas } \\
\text { marmūzę isikišimui (s. 188). }\end{array}$ \\
\hline 6. & $\begin{array}{l}\text { Gęba - powiedział Miętus - nic } \\
\text { szczerego, nic naturalnego, wszystko } \\
\text { naśladowane, tandetne, fałszywe, } \\
\text { skłamane (s. 196). }\end{array}$ & $\begin{array}{l}\text { Snukis - pasakè Mientus, - nieko } \\
\text { nuoširdaus, nieko natūralaus, viskas } \\
\text { pamėgdžiota, apgaulinga, sumeluota. } \\
\text { (s. 213). }\end{array}$ \\
\hline 7. & $\begin{array}{l}\text { Gębę miał [parobek] - ale gęba jego } \\
\text { nie była w niczym pokrewna fatalnej } \\
\text { gębie Miętusa, nie była to gęba } \\
\text { wytworzona, lecz naturalna, ludowa, } \\
\text { grubo ciosana i zwykła (s. 208). }\end{array}$ & $\begin{array}{l}\text { Snukį turèjo - bet jo marmūzè } \\
\text { niekuo nebuvo panaši i fatališką } \\
\text { Mientaus snukị, tai buvo ne sukurta } \\
\text { marmūzè, o natūrali, liaudiška, } \\
\text { netašyta ir banali (s. 226). }\end{array}$ \\
\hline 8. & $\begin{array}{l}\text { - Józio, widziałeś, przecie on ma } \\
\text { gębę - nie wysztafirowaną, ma gębę } \\
\text { zwykłą! Gębę bez miny! (s. 211). }\end{array}$ & $\begin{array}{l}\text { - Juzi, pats matei, jis turi snuki - } \\
\text { neišdabintą, turi paprastą paprasčiau- } \\
\text { sią snukị! Snuki be minos! (s. 229). }\end{array}$ \\
\hline 9. & $\begin{array}{l}\text { O, rozkoszy uderzenia przy świetle } \\
\text { po owym strachu w ciemnościach, } \\
\text { bić gębę, która straszyła, bić w ra- } \\
\text { mach określonych jasnym pojęciem } \\
\text { kradzieży! (s. 251). }\end{array}$ & $\begin{array}{l}\text { O, palaima mušti šviesoje po tos } \\
\text { baimės tamsybėse, mušti per } \\
\text { marmūzę, kuri kèlè baimę, mušti, } \\
\text { apsiribojus aiškia vagystès sąvoka! } \\
\text { (s. 274). }\end{array}$ \\
\hline 10. & $\begin{array}{l}\text { - Nie kradłeś? - powiedział Kons- } \\
\text { tanty i nachyliwszy się z krzesła } \\
\text { palnąl w pysk. Nie kradłeś! - powie- } \\
\text { dział panicz i dal w pysk... (s. } 251 \text { ). }\end{array}$ & $\begin{array}{l}\text { - Nevogei? - tarè Konstantinas ir } \\
\text { pasilenkęs krèsle žiebė ị snukị.-- } \\
\text { Nevogei? - tarè ponaitis ir trenkè } \\
\text { i dantis ... (s. } 274) \text {. }\end{array}$ \\
\hline 11. & $\begin{array}{l}\text { Nie bili się z nim - nie bili go - tylko } \\
\text { po mordzie dawali! I to im było } \\
\text { dozwolone (s. 253). }\end{array}$ & $\begin{array}{l}\text { Nesimušè su juo - nemušè jo - tik } \\
\text { pylè per snukị! Šitai jiems buvo } \\
\text { leidžiama (s. 276). }\end{array}$ \\
\hline 12. & $\begin{array}{l}\text { Gdyż nie ma ucieczki przed gębą jak } \\
\text { tylko w inną gębę, a przed człowie- } \\
\text { kiem schronić się można jedynie } \\
\text { w objęciach innego człowieka [...] } \\
\text { Uciekam z gębą w rękach (s. 264). }\end{array}$ & $\begin{array}{l}\text { Nes neįmanoma pabègti nuo snukio } \\
\text { kitaip, kaip tik i kitą snukị. O } \\
\text { apsisaugoti nuo žmogau galima tik } \\
\text { kito žmogaus glèbyje [...] Bègsiu nuo } \\
\text { jūsų su snukiu rankoje (s. 288). }\end{array}$ \\
\hline
\end{tabular}

Tabela 3. Przekład pojęcia „gęba” w litewskiej adaptacji powieści W. Gombrowicza Ferdydurke.

W przekładzie tego pojęcia tłumaczka posługuje się dwoma litewskimi odpowiednikami: snukis i marmūzè. Leksem snukis jest wieloznaczny, LKŽ notuje następujące jego znaczenia: 1) 'przednia część głowy, pysk zwierzęcia, na przykład świni, krowy, owcy'; 2) 'dziób’; 3) 'jama gębowa (zwierząt)'; 4) lekc. 'twarz'; 5) 'podbródek'; 6) lekc. 'usta'; 7) 'przed- 
nia część czegoś'. Widzimy zatem, że w podstawowym znaczeniu nazywa on część głowy ptaka lub zwierzęcia i tylko w przenośnym określa ludzką twarz. Drugi wymiennie stosowany wyraz marmūze , derywowany od czasownika marmuzyti 'gadać głupstwa', ma tylko jedno zabarwione emocjonalnie znaczenie: lekc. 'twarz, usta'. W odniesieniu do człowieka wartość stylistyczna obu wyrazów jest jednakowa, mają one nacechowanie lekceważące, a nawet mogą być obocznie stosowane we frazeologizmach: ị snukị/marmūzę duoti 'dać komuś w pysk', $i$ (per) snukị/marmuze gauti 'dostać w mordę/po pysku'.

Wymienne stosowanie tych synonimów w przekładzie utworu Gombrowicza nie sprzyja jednak ustabilizowaniu się któregoś z nich w funkcji odrębnej nazwy, a zatem wykrystylizowania i samego pojęcia maski wytwarzanej w relacjach międzyludzkich. Taka oboczność różnych litewskich leksemów zdarza się nawet w jednym zdaniu, jak chociażby w przykładzie 7 , gdzie w oryginale słowo gęba pojawia się aż czterokrotnie, a jego powtórzenie służy uwydatnieniu w tej scenie nazywanego pojęcia. W wersji litewskiej natomiast występują dwa różne odpowiedniki, co może sugerować błędną interpretację, że za każdym z nich kryje się inne znaczenie.

W przekładzie nie zachowały się też Gombrowiczowskie neologizmy frazeologiczne robić/wlepić komuś gębę, ponieważ potraktowano je nie jako idiomy, lecz jako luźne połączenia, które przetłumaczono w różny sposób, na przykład robić komuś gębę jako daryti marmūzę (przykład 3) i daryti snuki (przykład 4), wlepić komuś gębę jako įtaisyti marmūzę (przykład 1) i ịlipdyti snuki (przykład 2).

Poza tym wyraz snukis pojawia się w opisie sceny bicia parobka po twarzy za domniemaną kradzież i w tym kontekście jest odpowiednikiem polskich ekspresywów pysk i morda (por. przykład 10,11), które określają lekceważąco twarz, ale nie mają żadnych głębszych konotacji. Nie zawsze dostrzeżone też zostały subtelności składni, które mogą aktualizować określone znaczenie, na przykład związek składniowy bić gębę (przykład 9) potraktowano podobnie jak połączenie z przyimkiem dawać po mordzie (przykład 11), choć rząd biernikowy czasownika bić kogo/co jest bardziej wieloznaczny, ponieważ zakłada zarówno obiekt osobowy, jak i nieosobowy. 


\section{Wnioski}

Z powyższych rozważań wynika, iż przekład zaczerpniętych z języka potocznego wyrazów oznaczających Gombrowiczowskie pojęcia o nadbudowie filozoficznej nie jest sprawą tak prostą. Ich wielokrotne powtarzanie w tekście powieści powoduje, że istotnie wpływają one na rozwój akcji i dlatego nie można ich w przekładzie obejść za pomocą takich technik przekładu, jak pominięcie, parafraza czy użycie hiperonimu, lecz należy szukać najbliższych ekwiwalentów. W litewskiej wersji powieści posłużono się odpowiednikami bliskimi semantycznie, ale różniącymi się pod względem zakresu znaczeniowego oraz stylistyczno-pragmatycznego: pupa przetłumaczono jako užpakalis (rzadziej - užpakaliukas), tydka jako blauzda, gęba jako snukis oraz marmūzè.

Najbliższy oryginałowi jest litewski odpowiednik nazwy łydka - blauz$d a$. Te neutralne emocjonalnie wyrazy nabierają odpowiednich konotacji zarówno w języku wyjściowym, jak i docelowym dzięki trafnym kolokacjom i kontekstowi - pojawiają się bowiem w opisie młodej pensjonarki i mają symbolizować młodość, nowoczesność i swobodę obyczajową.

Pozostałe wyrazy litewskie nie są dokładnymi ekwiwalentami stylistyczno-pragmatycznymi i mają nieco inne konotacje. W języku litewskim zabrakło bliskiego odpowiednika wyrazu pupa, który nie tylko nazywałby trywialną część ciała, ale też bezpośrednio kojarzył się z niedojrzałością. Te straty translatorskie o charakterze pragmatycznym w pewnym stopniu kompensują towarzyszące litewskiemu odpowiednikowi užpakalis określenia vaikiškas 'dziecięcy', infantilus 'infantylny', a przede wszystkim sam karykaturalny mikroświat szkoły, której administracja próbuje zapędzić młodzież w niedojrzałość i narzucić infantylizm na całe życie. Tłumacz czasami używa formy zdrobniałej užpakaliukas lub stosuje funkcjonalne techniki przekładowe, na przykład oddaje neologizm upupić za pomocą derywatu o dosłownej podstawie słowotwórczej suvaikinti.

Najmniej udane wydaje się rozwiązanie translatorskie przyjęte w przypadku tłumaczenia pojęcia „gęba”. Mając do dyspozycji kilka nacechowanych wyrazów potocznych, tłumaczka posługuje się dwoma spośród nich: wyrazem snukis, którego lekceważący odcień emocjonalny wynika z przenośnego znaczenia, oraz derywatem marmūze motywowanym przez nacechowany czasownik z pola znaczeniowego mówić. Wydaje się, że ten drugi 
jest bliższy pojęciu maski w relacjach miedzyludzkich. Sam jednak fakt wymiennego używania dwu wyrazów w litewskim przekładzie nie służy ustabilizowaniu się niezmiernie ważnego dla symbolicznej wymowy powieści pojęcia.

\section{Bibliografia}

Bańkowski A., Etymologiczny słownik języka polskiego, t. 2, Warszawa 2000.

Bolecki W., Przewodnik po labiryncie, [w:] Witold Gombrowicz, Ferdydurke, Kraków 2007.

Dąbrowska A., Eufemizmy współczesnego języka polskiego, Łask 2006.

Gombrowicz W., Dziennik 1953-1956, Kraków 1997.

Gombrowicz W., Ferdydurke, Kraków 2007.

Gombrowicz W., Ferdydurkè, vert. Irena Aleksaitè, Vilnius 2004.

Hejwowski K., Kognitywno-komunikacyjna teoria przekładu, Warszawa 2012.

Jarzębski J., Między chaosem a formą - Witold Gombrowicz, [w:] Prozaicy dwudziestolecia międzywojennego. Sylwetki, red. B. Faron, Warszawa 1972.

Skibińska E. (red.), Gombrowicz i tłumacze, Łask 2004.

Słownik języka polskiego, red. W. Doroszewski, t. I-XI, Warszawa 1958-1969.

Stownik synonimów polskich, red. Z. Kurzowa, Warszawa 2003. 